\title{
Koreografi Episode Hitam Manusia Pandemi
}

\author{
Hendro Martono ${ }^{1}$, Tamata Nona Armanda ${ }^{2}$ \\ 1,2Jurusan Tari, Fakultas Seni Pertunjukan, Institut Seni Indonesia Yogyakarta \\ Jalan Parangtritis Km 6,5 Yogyakarta Kotak Pos 1284
}

${ }^{1}$ hendromartono401@gmail.com

\begin{abstract}
Merebaknya pandemi virus Covid-19 yang mematikan mengancam kehidupan manusia seluruh dunia,rakyat kecil yang bekerja informal menghadapi pilihan sulit harus memilih antara bekerja demi kelangsungan hidup atau terinfeksi virus. Penelitian ini menjadikan mahasiswa Tari yang menjadi obyek penelitian dan sumber garapan tari, ada yang berkerja menjadi penari untuk acara pariwisata dan company gathering maupun menari untuk kepentingan kraton Yogyakarta . Selama ada pandemi semua kegiatan pariwisata lumpuh total, mahasiswa tidak mendapat pemasukan uang bila harus mengikuti anjuran pemerintah work from home. Mahasiswa yang biasanya mendapat penadapatan untuk menopang kebutuhan sehari hari, juga mengalami episode hitam, kebingungan tidak bisa mengungkapkan hasratnya sebagai penari, kecuali di sosial media. Isu kemanusiaan dalam menghadapi pandemi, dalam Bahasa Jawa Ora Obah Ora Mamah artinya tidak bekerja maka tidak bisa makan, menjadi tema koreografi. Gagasan tersebut diekspresikan ke media tari kontemporer menggunakan metode Proses Kreatif Koreografi Lingkungan dan pendekatan Intersubyektif. Didukung tata artistik yang membatasi ruang gerak penari berupa trap kayu, yang menjadi simbol terkungkung di ruang yang sempit. Musik tari diunduh dari Youtube yang dipilih sesuai dengan konsep Tik Tok di media sosial untuk menguatkan nuansa dramatik serta ekspresi tari. Perancangan tari terwujud dalam 2 bentuk koreografi tunggal lengkap dengan pendukung tata cahaya dan artistik yang direkam video dan foto berdurasi sekitar 6 menit untuk masing masing koreografi. Menggunakan TKT 5 Validasi prototipe/produk/karya seni skala studio.
\end{abstract}

Kata kunci : episode, hitam, pandemik, obah, mamah

\section{The Choreogaphies Of The Dark Episode Of People InPandemic}

The spread of Covid-19 the deadly pandemic threatens people all over the world. Informal workers must face the difficult decision between working for survival and being infected by the virus. The present study used Dance students as the research subjects and dance inspiration. Some of them work as dancers in tourism events and company gathers, as well as for Yogyakarta kraton. During the pandemic, tourism activities completely stop, so that the students won't earn any money if they follow the government's suggestion to work from home. Students who usually get income to meet their daily needs face a dark episode, unable to express their desire to dance except on social media. Humanity issue in a pandemic in Javanese is Ora Obah Ora Mamah, meaning if you don't work, you can't eat. It became the choreography theme. The idea is expressed in contemporary dance using Environmental Choreography Creative Process and Inter-subjective approach. It's supported by artistic set which limits the dancer's space using wooden traps, symbolizing being trapped in a narrow space. The music is music suitable for Tik Tok concept on social media downloaded from Youtube to strengthen the dramatic atmosphere and dance expression. The dance designs were two single choreographies complete with lighting setup and artistic setup recorded in videos and photos. Each choreography is around 6 minutes long. They use TKT 5 Studio scale prototype/product/artwork validation.

Keywords: episode, dark, pandemic, move, eat

Proses Review : 1 - 30 Juni 2021, Dinyatakan Lolos: 15 Juli 2021 


\section{PENDAHULUAN}

Di awal tahun 2020 hingga merambah ke beberapa bulan kemudian, dunia diteror oleh virus Corona atau disebut Covid-19 yang tidak kasat mata namun mematikan. Kalanagan birokrat sibuk membuat peraturan pembatasan perjumpaan manusia di segala kegiatan, baik ibadah, kerja, maupun bermasyarakat. Untuk membatasi penyebaran virus yang hanya bisa antar manusia. Di kala banyak negara lain berhasil menekan transmisi Covid-19 dengan cara lockdown, Pemerintah Indonesia tidak memilih cara ini sebagai solusi memerangi virus corona. Seorang Epidemiologist Researcher Imperial College London, Dr Dian Kusuma, menyarankan, Indonesia masih perlu melakukan lockdown, meskipun sistemnya bisa berbeda dengan lockdown yang dilakukan oleh negara lain. Pengalaman negara-negara lain dan keberhasilan dalam menangani kasus Covid-19 yang sedang mewabah di lebih dari 200 negara saat ini (Kompas.Com.https://www. cnbcindonesia.com/ne ws/20200410064937-4-151040/ psbbjakarta-mulai-berlaku-ini-yang-boleh-tak-boleh-didki, diunduh 15 April 2020)

Jadi yang terbayangkan saat menyebut kata lockdown adalah sistem yang diberlakukan oleh negara China, seperti yang diketahui adalah melakukan penutupan akses keluar dan masuk di wilayah Kota Wuhan, Provinsi Hubei, China, yang sekaligus merupakan asal mula pandemik virus corona baru SARS-CoV-2. Tidak hanya akses, masyarakat di kota terisolasi itu pada masa lockdown memang tidak diperbolehkan untuk melakukan segala aktivitas di luar rumah, termasuktidak boleh mengungsi ke daerah lain. Lockdown yang berlangsung hampir dua bulan di Wuhan tidakhanya membuat tempat itu seperti kota tak berpenghuni. Saat lockdown dilakukan, stok kebutuhan makanan juga sempat hampir menipis. Dicontohkan, Malaysia melakukan lockdown yang sifatnya karantina wilayah parsial. Jadi untukkebutuhan pokok, pembersihan, dan petugas kesehatan tetap terus berjalan (Ellyvon Pranita, artikel kompas.com "Indonesia Tak Pilih Lockdown untuk Perangi Corona, Begini Kata Ahli...," diunduh 15 April 2020).

Pemerintah Indonesia melakukan pembatasan yang lunak, dampaknya orang yang terinfeksi Corona terus meningkat cepat. Presiden Jokowi tidak melakukan lockdown total hanya PSBB yang dikeluarkan oleh gubernur Jakarta. Alasan tidak lockdown di Jakarta, karena merupakan pusat perdagangan, pusat pemerintahan, dan pusat perekonomian Indonesia. Bila di lockdown dikhawatirkan terjadi kerusuhan seperti penjarahan karena masyarakat kecil sebagai pekerja non formal yang jumlah jutaan di Jakarta. Ada peribahasa Jawa Yen Ora Obah Ora Mamah artinya bila tidak bekerja tidak bisa makan. Sehingga orang masih ramai berkeliaran di jalanan, seperti penjual warung, pedagang asongan, penjual di pasar, ojol, pemulung dan ribuan jenis pekerjaan non formal lainnya. Situasi sekarang ini juga melibas semua sendi perekonomian rakyat dan negara. Peternakayam, telor, ikan, udang dan petani sayuran kebingungan mencari pembeli, sementara barang dagangan numpuk membusuk. Berbagai upaya ditempuh dengan menawarkan barangnya secara online atau banting harga.

Kesulitan hidup dari sudut kemanusiaan di masa pandemi Corona menjadi renungan yang selalu mengusik di kalbu penulis, masyarakat bagaikan menghadapi pilihan yang sulit antara ingin hidup tetapi tidak bisa makan karena tidak punya uang dengan pilihan tetap bekerja tetapi diteror oleh virus yang mematikan. Pada kesempatan karya kali ini mengeksplorasi sisi kemanusiaa orang yang terkena pandemi, padahal manusia hidup terbiasa bersosialisasi namun satu keadaan yang membuat terisolasi, adanya pembatasan sosial pada semua sendi kehidupan bermasayarakat maupun beribadah. Situasi yang ada dimasyarakat golongan ekonomi lemah terjadi tarik ulur antara mematuhi larangan pemerintah dengan kebutuhan hidup. Pada setiap kesempatan berdialog dengan penjual makanan atau warung tentang pembatasan sosial selama pandemi Covid 19, mereka menyampaikan alasan yang sangat rasional bila tidak bekerja, keluarganya tidak bisa makan. Virusyang mematikan tidak menyurutkan kegiata masyarakat ekonomi lemah untuk tetap bekerja, maka pasar dan pertokoan serta pedagang kaki lima ramai kembali setelah dua minggu tutup. Walaupun ada protokol yang harus dipatuhi, minimal mengenakan masker dan sering cucitangan dan tidak bersentuhan atau berdekatan dengan orang lain. Situasi maraknya orang orang berkeliaran lagi untuk bekerja membuat penyebaran virus semakin luas dan memperbanyak yang terkena virus Corona.

Kegiatan mahasiswa Tari yang terkena pandemi, hampir mirip dengan masyarakat pada umumnya, hanya ada keunikan yang tersendiri, mahasiswa adayang memainkan game online dan menonton film drama Korea yang online atau mengunduh secara lebih sering, Mereka kuat berjam jam di depan laptop atau handphonenya. Ada juga yang melakukan seperti berdandan atau dengan menor, lengkap berpakaian seakan akan mau jalan jalan, di foto dengan gaya menari atau gerak gerak yang lucu lalu diunggah ke sosial media, bisa di instagram stori, facebook, atau Likee, setelah itu masak bersama sama kawan kos, lalu makan bersama kemudian tidur kelelahan. Namun pada kenyataannya hanya di kamar kontrakan saja mengisi kegiatan mengusir kejenuhan, tidak bisa jalan jalan di mall dan nonton bioskop. Ada beberapa mahasiswa yang berasal dari luar kota bahkan pulau tidak bisa balik ke kampung halamannya karena dilarang orang tua, dengan alasan di daerahnya juga menjadi daerah merah Covid-19. Ada beberapa mahasiswa asli Yogyakarta, lebih senang tetap di kamar kontrakan bersama beberapa kawan kuliah untuk mengisi kegiatan bersama daripada bengong di rumah tidak ada kawan untuk berkegiatan. Pada awal lockdown, ada beberapa mahasiswa masak bersama lalu 
dibungkus kemudian disedekahkan ke orang orang yang membutuhkan. Pada awal pembatasan social sekitar bulan Maret-Mei 2020 ada beberapa orang memajang nasi bungkus gratis di tepi jalan untuk orang orang yang tidak bisa bekerja mendapatkan uang, seperti ojek online. Terrnyata kampus masih di tutup hingga bulan Oktober 2020, padahal banyak mahasiswa yang dari luar daerah sudah kembali ke Yogyakarta. Kondisi gtersebut semakin membuat mahasiswa frustasi dan bosan dengan berdiam diri walaupun tetap kuliah daring dari kamar kontrakannya. Mereka ingin kembali merasakan kuliah bersama sama dengan kawan dan dosennya di kampus. Apalagi bidang seni yang sangat membutuhkan interaksi langsung antar manusia.

Adapun tujuan penelian dan penataan karya tari ini untuk meningkatkan kemampuan dosen dan mahasiswa sebagai anggota peneliti untuk mewujudkan tari Episode Hitam yang bersumber dari perilaku mahasiswa tari dalam menyikapi situasi pandemi. Mewujudkan kepemilikan Kekayaan Intelektual dalam koreografi. Menambahkan wawasan berkesenian bagi mahasiswa anggota peneliti, dalam berproses kreatif membuat koreografi tunggal, karena koreografi tunggal jarang dilakukan oleh para seniman tari. Situasi pandemi yang membuat seniman tari berani tampil sendiri. Membawa koreografi ke zaman virtual yang diunggah ke sosial media agar lebih dikenal oleh masyarakat luas tanpa pergelaran.

Teori yang digunakan metode konstruksi 1 \& II Jacqueline Smith, Diawali rangsang terdiri yaitu: Gagasan, Visual, Kinestetik Pendengaran dan Rangsang Peraba. (Jacqueline Smith, terjemahanBen Suharto, 1985:20-23).

Tahap berikutnya adalah menentukan Tipe tari yang terdiri dari: Murni, Studi, Abstrak, Dramatik, Dramatari, Liris, Komik. Sedangkan Mode Penyajian Tari adalah Simbolis dan Representatif (Jacqueline Smith, terjemahan Ben Suharto, 1985:24).

Metode Konstruksi II Jacqueline Smith memberikan praktek pengembangan motif gerak yang berdasarkan Aksi, Tenaga/Usaha, Ruang dan Tata Hubungan. (Jacqueline Smith, terjemahan Ben Suharto, 1985: 36 39). Pengulangan menjadi perhatian Metode Konstruksi II karena untuk memberi penegasan pada suatu motif gerak yang menarik secara artistik ataupun secara dramatik, jangan sampai motif gerak yang bagus hanya tampak sekilas saja bila tidak diulang. Ada beberapa jenis pengulangan seperti: Penguatan Kembali, Rekapitulasi, Gema Ulang, Mengingat Kembali, Pernyataan Ulang dan Revisi yang memiliki penjelasan yang berbeda beda (Jacqueline Smith, terjemahan Ben Suharto, 1985: 40 41). Pengembangan gerak dalam Metode Konstruksi II ini memang sangat detil kadang kadang terjebak ke suatu proses yang bersifat pasti atau matrik yang mengabaikan rasa kinestetik. Teori Metode Konstruksi diharapkan memberikan kemudahan dalam pengembangan motif gerak dalam koreografiEpisode Hitam.

Teori koreografi tersebut untuk memudahkan klasifikasi tarian yang ditata, agar lebih mudah dan jelas bagi peneliti dalam berproses kreatif. Dengan demikian konseptual koreografi sudah tertulis yang digunakan dasar pijakan ke tahap proses kreatif selanjutnya yaitu proses koreografi. Dalam berproses sangat dimungkinkan adanya perubahan dari konsep koreografi yang berdasarkan metode konstruksi Jacquline Smith tersebut. Konsep koreografi bukan harga mati yang tidak bisadiubah, melainkan lentur bisa disesuaikan dengan adanya tambahan gagasan dari penata tari.

Kontribusi penciptaan tari yang berdasarkanpenelitian ini adalah menjadi referensi bagai mahasiswa dalam berkarya tari tunggal dan meningkatkan empati seniman terhadap situasi pandemi. Menjadikan momen koreografer untuk belajar atau menambah pengetahuannya tentang seluk beluk teknik unggah di sosial media sekaligus belajar sinematografi dalam mendokumentasikan karya tarinya untuk keperluan daring sebagai pengganti pementasan. Diharapkan tarian yang diciptakan ini bisa menjadi sarana edukasi bagi anak anak maupun masyarakat luas, bahwa situasi pandemi tidak menyurutkan semangat seniman dalam penelitian dan penciptaan seni.

\section{METODE PENCIPTAAN}

\section{Pendekatan Koreografi Lingkungan}

Menggunakan pendekatan Koreografi Lingkungan yang merupakan intisari cara berkesenian seniman Nusantara yang sangat mengenal lingkungan hidupanya dan dari lingkunganlah inspirasi seni bisa hadir secara bijak, bukan sesuatu yang tiba tiba ada melainkan selaras dengan ekspresi lingkungan. Maka dari itu panca indra lebih ditekankan pada proses kreatif disamping tubuh yang sudah peka terhadap segala stimulus dengan berbagai pengalaman gerak menjadi ujung tombak dalam pendekatan ini. Meliputi:

Sensasi Ketubuhan, atau penubuhan yang sering disebut dengan istilah embody. Suatu proses mengamati, menikmati secara mendalam denganmenyentuh langsung, menjadikan sadar atas gejolak jiwa yang telah menyatu dengan sesuatu yang ditangkap oleh indrawi (Hendro Martono, 2012: 115). Dilakukan dengan bergerak tanpa ada keinginan pamer kepenarian tetapi bergerak yang ringan, mengalir, lembut, pelan tanpa ada penekanan kekuatan gerak, untuk membantu konsetrasi dilakukan sambil menutup mata.

Menajamkan penglihatan, mata sebagai indra yang memegang peranan penting saat mengenali daerah baru beserta masyarakat dan alam lingkungannya. 
Menajamkan pendengaran, mendengar secara seksama soundscape daerah baru tersebut. Suara apa yang paling dominan, suara mesin motor, mesin pabrik, suara air, suara angin, burung, binatang peliharaan dan suarasuara lain yangterabaikan oleh masyarakat setempat.

Menajamkan, penciuman dan sentuhan secara indrawi tanpa bantuan mata. Begitu juga saat meraba, menyentuh dengan mata terpejam akan memberi sensasi yang berbeda. Penjelajahan ruang baru di masyarakat, akan melahirkan gagasan gagasan baru pula yang kreatif dan inovatif. Keunikan suatu ruang menjadi nilai tersendiri yang dapat menggugah atau menstimulan seniman maupun penonton untuk mengetahui lebih dalam tentang hal-hal yang tersembunyi di suatu ruang yang baru. Ada nilai pembelajaran bagi semua orang dan dapat menjembatani berbagai kepentingan antara masyarakat dengan seniman maupun penonton, terhadap adanya fenomena sosial yang sedang berlangsung di ruang baru tersebut.

Sensasi Emosi, yang ditimbulkan setelah menerima sentuhan berbagai perasaan dalam menghadapi kehidupan, menjadikan sadar terhadap sensasi emosional (Hendro Martono, 2012: 116). Sensasi emosi ini merupakan kelanjutan dari sensasi ketubuhan, yang sudah melibatkan emosi atau perasaan tentang sesuatu yang dapat menghadirkan gagasan seni. Kalau sensasi ketubuhan, membiarkan tubuh serta seluruh indrawi menangkap sembarang objek untuk mengenali terlebih dulu.

Sensasi Imaji, akses tambahan kemampuan kesenimanan yang dapat memutar kembali imajinasi atau gambarangambaran untuk dijadikan sebuah karya seni baru karena proses kebebasan koreografer dengan imajinasinya dapat timbul, membuka dan merubah satu kebiasaan yang senantiasa berubah- ubah cepat (Hendro Martono, 2012: 116). Mulai menemukan gambaran- gambaran atau bayangan tari menari di angan koreografer, ilusi-ilusi tersebut segera didokumentasikan dengan corat-coret lukisan ataupun dengan tulisan serta simbolsimbol yang diciptakan sendiri pada sebuah catatan khusus.

Ritus Ekspresi, penemuan kualitas estetis adalah hubungan integral dari imajinasi dan penyusunan melalui perasaan. Hal itu dapat timbul dari suatu akumulasi rasa dan imajinasi yang ditransformasikan ke gagasan gerak melewati pengalaman yang orisinalitas. Transforming darigambaran imajiner ke wujud gerak yang nyata, sangat bergantung pada kemampuan koreografer dan kerjasamanya dengan penari (Hendro Martono,2012: 116). Tahapan ini melalui proses kreatif inovatif yang mampu menciptakan living form, bukan sekedar merangkai gerak fisikal atau matrik namun gerak yang berdaya hidup.

\section{Pendekatan Intersubyektif}

Sebuah pendekatan yang belum tertulis secara metodis dan sistematis sehingga memuat pengetahuan ilmiah yang berawal dari sistem kerja kreatif seniman tradisional. Hampir mirip dengan sistem kerja Kolaboratif, namun sangat berbeda kalau Kolaboratif sejak awal penyusunan konseptual seni yang akan diproduksi dilakukan bersama oleh beberapa seniman. Menampung semua gagasan bersama dan didiskusikan panjang lebar hingga detil pembiayaan, para pendukung, prosesnya hingga pergelarannya ditanggung bersama. Intersubyektif, gagasan konseptual dari awal hingga akhir dilakukan oleh seseorang yang kemudian melibatkan beberapa pemain senior yang memerankan keahlian seniman senior tersebut. Tanggung jawab artistik dan produksi berada di tangan koreografer.

Sampai saat ini masih banyak seniman nusantara maupun seniman akademisi yang menerapkan metode intersubyektif ini, yaitu mempercayakan sepenuhnya kekuatan ketubuhan serta kreativitas kepenari yang dipilih. Koreografer hanya membeberkan konsep secara garis besar sertarencana gerak serta pemanggungannya kepada penari terpilih atau asisstennya. Eksekusinya perwujudan tari diserahkan sepenuhnya kepada penari tersebut. Koreografer duduk mengamati sambil mengevaluasi saat itu juga kepada penari yang berlatih. kadang berteriak memberikan arahan seperti yang dilakukan almarhum Bagong Kussudiardja. Penari yang sudah terbiasa sudah mengerti arti teriakan yang kadang kurang jelas diksinya karena tertimpa suara musik tari, Bagong Kussudiardja bila memimpin garapan tari massal yang melibatkan ratusan penari berdiri di atas tempat yang tinggi sambil memegang microphone atau megaphone agar suaranya bisa diterima oleh semua penari di lapangan. Bagong memiliki beberapa asisten juga sebagai inter personal yang akan melatih penari yang lainnya, di antaranya Ida Manutranggono (almarhum), Ngatini, Sutopo (almarhum), Sunardi dan Flori Fonno dari Kupang. Peneliti sebagai penata cahaya telah beberapa kali mengikuti proses kreatif Bagong Kussudiardja saat menggarap tari dengan penari massal maupun dengan penari terbatas.

Beda dengan Sardono W. Kusumo menggunakan metode intersubyektif dengan mendekati kemudian membisiki evaluasinya ke penari, maka hanya penari tersebut yang memahami evaluasinya. Peneliti pernah mengikuti proses kreatif Sardono saat menggarap Diponegoro, dan garapan tari lain nya yang melibatkan ratusan orang dan seniman berbagai bidang seni. Paling tidak dengan penata musik dan penata busana. Sardono sering mengadakan karya dengan intersubyektif bersama pianis, perupa bambu, pelukis, penulis buku dan bintang film.

Sardono dalam suatu kesempatan di tahun 2000, pernah menyampaikan secara oral bahwa metode intersubyektif tersebut, yang diamati sejak lama yaitu dalam proses penciptaan tari tradisionalseperti Wayang Wong, Bedhaya, Sendratari dan sebagainya. Dicontohkan beberapa penari senior yang telah masuk ke karakter perannya seperti 
Jayasentika penari Cakil dari Yogyakarta, cara berjalan dan cara bicara sudah mirip dengan Cakil. Maka bila melibatkan penari Cakil tersebut ke dalam Wayang Wong diberi kebebasan menginterpretasi sendiri hasilnya lebih maksimal daripada mengikuti ide penata tarinya yang belum tentu menguasai karakter Cakil tersebut. Di Wayang Wong Sri Wedari Surakarta, tahun 70-80 dulu ada Surono Petruk/Gareng, Rusman sang Gatutkaca yang mendalami karakternya secarabrilian.

Simpulan Pendekatan Intersubyektif: Ada kerjasama dua orang atau lebih, bisa berbeda bidang seni. Memahami konsep seni pertunjukan yang akan diciptakan dengan pemahaman yang sama. Saling menghargai karya orang lain yang terlibat. Diperlukan diskusi panjang yang matang dalam menyambung dan merekatkan antar bagian karya yang satu dengan lainnya. Secara artistik karya menjadi tanggung jawab seseorang penata tari yang membuat konseptual koreografinya.

Peneliti sudah sering menerapkan pedekatanintersubyektif dalam berkarya seni, termasuk dalam proses kreatif Episode Hitam Manusia Pandemi. Pada kesempatan ini peneliti selaku koreografer melibatkan dua mahasiswi tari yang memiliki ketubuhan yang bagus dan berkarakter antar satu dengan yang lain berbeda. Tamara Nona Armanda mahasiswa asli Yogyakarta lulusan SMK Negeri 1 Kasihan Bantul atau dulu SMKI jurusan Tari, seorang penari Jawa yang juga bagus ketubuhannyadalam garapan kontemporer. Ni Made Oliftyansi Santi Dewi dari Bali yang ketubuhannya juga bagus menarikan tradisi maupun kontemporer. Penata tari hanya membeberkan konsep koreografi dan gambaran koreografi tunggal jke penari, ekspresinya sepenuhnya dengan pengawasan penata tari.

Dalam proses latihan awal, penari diberi stimulan melalui auditif yaitu musik untuk menjelajahi gerakyang sesuai dengan tema. Musik yang diperdengarkan juga merupakan eksplorasi dari beberapa musik yang diunduh dari Youtube. Deo memiliki dasar ketubuhan penari Bali, sedangkan Tamara ketubuhannya tari Jawa, jelas dua karakter yang berbeda. Sensasi Ketubuhan dasar gerak masing masing ditanggalkan dahulu, gerak bebas sesuai dengan kemampuan ketubuhan masing masing. Dua penari berlatih menyesuaikan tubuhnya dengan kosep koreografi. Peneliti menginginkan sebuah koreografi yang sederhana mudah dimengerti penonton. Dikarenakan perhitungan waktu yang sempit dan pembatasan sosial yang harus ditaati selama musim pandemi. Koreografi Lingkungan menyebutkan Sensasi Emosi dan Sensasi Imaji yang mulai membayangkan wujud detil gerak dan dramatisasi koreografinya. Setelah sekitar satu bulan latihan perminggu 2 × 2 jam, masuk ke tahap Ritus Ekspresi, satu tahap penataan terstruktur dengan unsur pendukung koreografi seperti properti tari dan properti panggung serta musik yang sudah sesuai dengan tariannya. Pola lantai hanya di sekitar trap kayu yang membatasi ruang tari. Durasi harus dibawa 10 menit setiap tarian, untuk pertunjukan virtual bila lebih dari 10 menit dikhawatirkan penonton sudah jenuh dan pindahmelihat acara yang lain yang lebih menarik.

\section{WUJUD KOREOGRAFI}

Stimulan dari gagasan yang terinspirasi dari sebuah peristiwa kemanusiaan terkena pandemi. Tipe tari Dramatik yang mengolah suasana yang dialami oleh manusia yang terkungkung di rumah karena adanya pandemi. Gabungan anatara rangsang Gagasan dengan Tipe tari Dramatik adalah yang paling umum digunakan, karena lebih mudah mengekspresikan dan mengatur permainan suasana. Penonton mudah menangkap maksud tarian tersebut. Mode penyajiannya yang dipilih adalah Simbolis, ada beberapa simbol dari properti taridan panggung, maupun gerak tarinya.

\section{Judul: Koreografi EPISODE HITAM MANUSIA} PANDEMI

Tema: Semangat hidup

Bentuk Ekpresi: Gerak tari bersumber dari gerak gerik orang yang terkurung di rumahnya sendiri, gelisah, bingung mau apa, sedih, berupaya berkegiatan yang lucu untuk menghibur diri dan sebagainya.

Penari: Tunggal oleh wanita.

Semula sesuai rencana proposal, akan menata satu koreografi duet, dengan penari laki laki dan wanita. Setelah observasi dengan wawancara kepada beberapa mahasiswa Tari yang masih tinggal diYogyakarta, artinya mahasiswa tidak kembali ke kampung halaman selama Belajar Dari Rumah (BDR). Didominasi mahasiswa wanita, ada beberapa mahasiswa laki laki, malahan sering gabung ke kelompok wanita bila berkegiatan, seperti masak memasak. Pada kenyataannya Prodi Tari memang di dominasi wanita. Peneliti memperhatikan di sosial media yang dominan mengisi Tik Tok, IG Stori dan sejenisnya adalah wanita, bila ada laki laki biasanya ikut kelompok wanita. Mengapa mereka masih senang menari bersama sama untuk konten media sosial walau hanya beberapa detik? Tari memiliki beberapa fungsi diantaranya disampaikan oleh RobbyHidayat:

"Seni tari sebagai media menumbuhkan kepribadian. Seni tari sebagai kegiatan sosial menempatkan individu dalam kerangka kebersamaan, atau dalam pribadi yang mandiri. Anak anak selalu dituntut mampu mengontrol dirinya, tetapi juga mampu bekerja sama dengan orang lain. Maka keyakinan akan kemampuan pribadi, dan ketcrgantungan pada orang lain dapat dibina secara simultan”. (Hidayat (2005:15) fungsi tari dalam pendidikan seni yang dikutib oleh Ni Luh Sustiawati Kontribusi Seni Tari Nusantara dalam Membangun Pendidikan Multikultur dalam Jurnal Mudra Volume 26, Nomor 2, Juli 2011). 
Situasitersebutkemudianmengubahrencanakoreografinya, menjadi koreografi tunggal yang dibawakan oleh wanita. Koreografi pertama diilhami dari situasi mahasiswi yang seperti terjebak di dalam kotak waktu, selama beberapa bulan hanya berkegiatan di dalam kamar. Paling sering main handphone untuk buat konten Tik Tok, komen atau main game online. Bila bosan lalu buka laptop nonton film yang paling sering ditonton film drama Korea. Hal itu dilakukan setelah kuliah daring. Maka koreografi pertama yang diberi judul Kotak Waktu, ditarikan oleh Ni Made Oliftyansi Santi Dewi mengekspresikan mahasiswi yang berkegiatan di dalam kamar, tata panggungnya juag ditata seperti di kamar wanita yang ada lampu hias thumbler serta tumpukan kotak kardus bekas. Properti tari menggunakan tisu, masker dan laptop. yang menguatkan judul dan tema tari.

Tari ke dua diberi judul Mimpi di Atas Impian dibawakan oleh Tamara Nona Armanda, terinspirasi dari penari yang tidak bisa lagi pentas karena adanya pandemi. Paling tidak seminggu sekali penari bisa pentas untuk acara pariwisata di panggung Prambanan atau pada acara company gathering di Mall atau hotel. Tidak sedikit yang pentas untuk acara pernikahan dan untuk kepentingan Kraton Yogyakarta. Semua kegiatan pentas dibekukan sehingga berimbas pada mahasiswa Tari, biasanya dapat uang pada setiap pentas menjadi tidak ada lagi pemasukan.Kemudian untuk mengisi kekosongan, mereka ada yang membuat Tik tok. Mahasiswa memimpikan pandemi segera sirna agar bisa pentas dan mendapat pemasukan lagi untuk membeli kuota atau alat riasnya yang sudah habis. Mimpi di Atas Impian adalah judul yang tepat pada tari yang mengekspresikan kegundahan penari di musim pandemi.

Tata panggungnya ditata seperti di atas tempat tidur, berserakan kain putih sebagai alas tidur di atas trap kayu. Di atasnya ada jaring hitam yang diberi gantungan kain perca bagaikan impian yang melayang di atas angan penari. Musiknya memadukan antara komposisi karawitan dengan ambient music yang menghadirkan nuansa tradisional Jawa di dalam kemasan kontemporer.

\section{Tata Rupa Pentas}

Tempat pentas: bisa tampil di mana saja, baik di proscenium stage (Hendro Martono, Ruang Berkesenian dan Pertunjukan, 2014: ) maupun di teater arena. Bila di luar ruangan akan memanfaatkan lingkungan sekitar menjadi pendukung artistik yang menguatkan koreografi seperti yang menjadi ciri utama dalam koreografi (Martono, Hendro, Koreografi Lingkungan: Revitalisasi Gaya Pemanggungan dan Penciptaan Seniman Nusantara. 2012: ), tempat tersebut hanya sebagai ruang untuk perekaman video dan pertunjukannya virtual sesuai dengan kondisi pandemic Covid - 19 .
Tata Rupa Pentas

Tari Mimpi Di Atas Impian
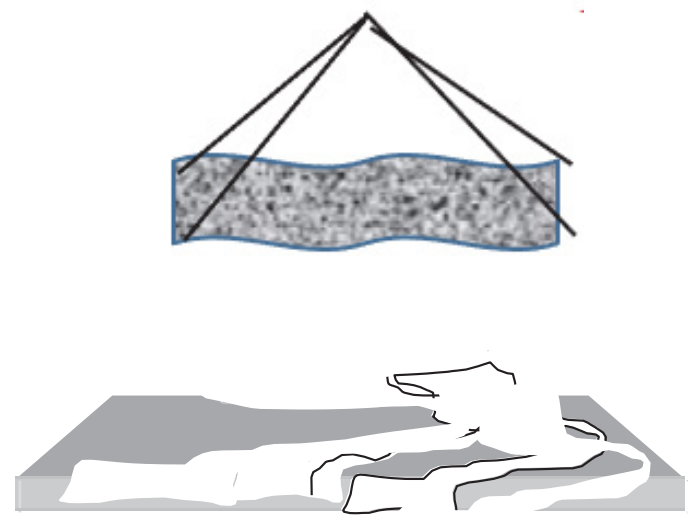

Gambar 1: Rencana tata rupa pentas, symbol rumahpada tari Mimpi Di atas Impian

Keterangan:

Trap kayu ukuran $240 \mathrm{~cm}$ x $240 \mathrm{~cm}$ tinggi 20ncm Kain lembaran berbahan lembut warna putih Paranet, ayaman tali raffia warna hitam yang biasa digunakan untuk peneduh tanaman.

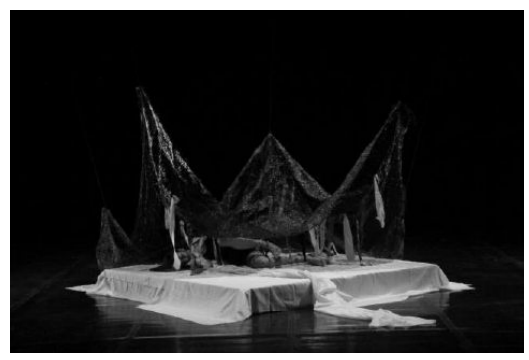

Gambar 2: Eksekusi tata rupa pentas, ymbol kamar wanita pada koreografi Mimpi Di atas Impian (foto: Ody, Agustus2020)

Tata Rupa Pentas Tari Kotak Waktu

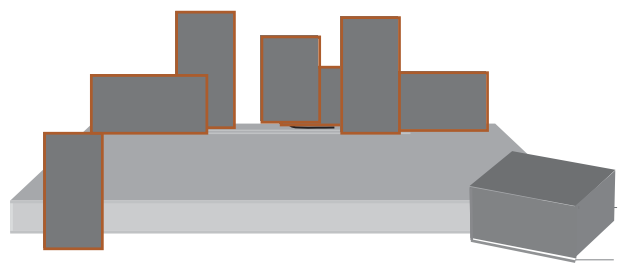

Gambar 3: Rencana tata rupa pentas, kardus bekas simbol keterbatasan ruang pada koreografi Kotak Waktu

Keterangan:

Trap kayu ukuran $240 \mathrm{~cm} \mathrm{x} 240 \mathrm{~cm}$ tinggi 20n cm Tumpukan kardus bekas berbagai ukuran 


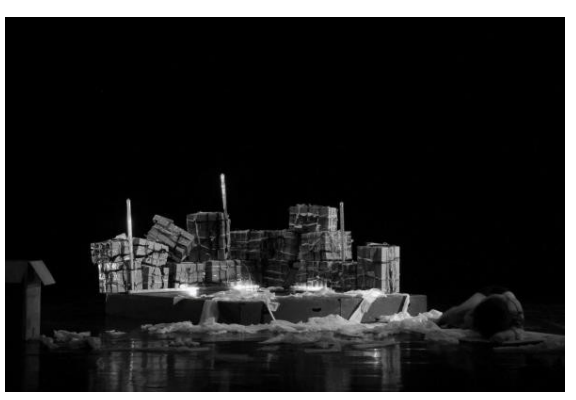

Gambar 4: Eksekusi tata rupa pentas, simbol keterbatasanruang pada Kotak Waktu (foto: Ody, Agustus 2020)

Rias dan Busana: disainnya sederhana hanya menggunakan celana pendek hitam dan kaos tank top hitam yang menggambarkan situasi di rumah.

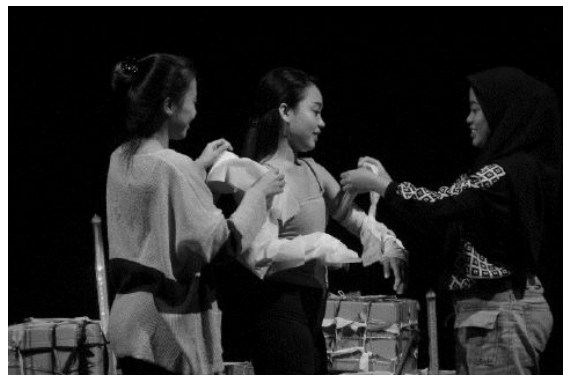

Gambar 5: Ni Made Oliftyansi, dibungkus dengan tisu di tangan dan kepala serta badannya (foto: Ody, Agustus 2020)

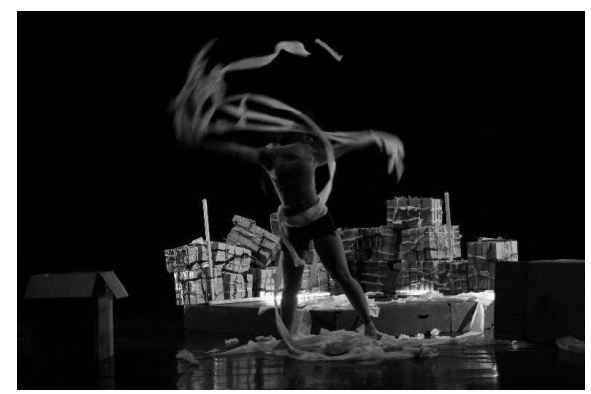

Gambar 6: Penari Kotak Waktu menggerakkan tisu yang di tubuhnya menciptakan disain tertunda (foto: Ody, Agustus2020)

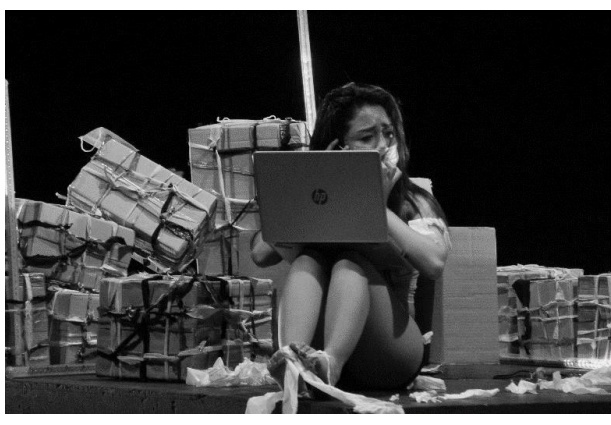

Gambar 7: Penari Kotak Waktu mengenakan masker danmemegang laptop (foto: Ody, Agustus 2020)
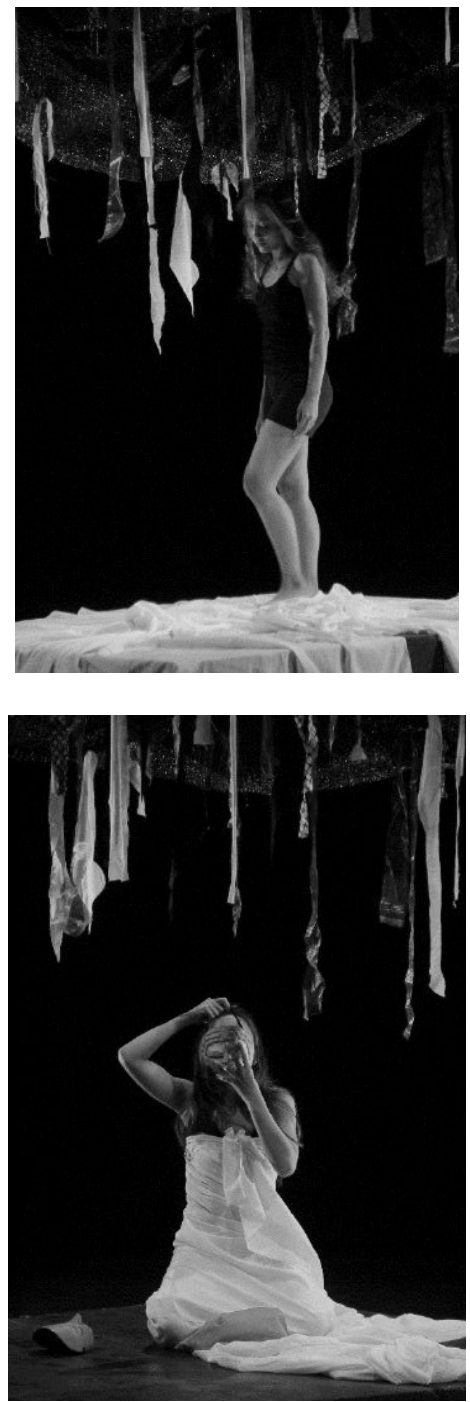

Gambar 8: Penari Mimpi di Atas Impian saat tampil tanpa lembaran kain (gambar kiri) dan saat bagian ending tubuhnya dibalut kain putih, mengenakan topeng dan masker (foto: Ody, Agustus 2020)

Musik Tari:

Menggunakan musik komputer awalnya, namun dengan pertimbangan pembatasan sosial dan keterbatasan anggaran maka musik menggunakan komposisi musik yang ada di Youtube. Dipilih yang sesuai untuk mencapai dramatisasi pada setiap adegan dan membungkus tarinya.

Tari Kotak Waktu, menggunakan musik editing yang diunduh dari Youtube bagian opening menggunakan musik efek dari Cinematic War Horn (Epic Movie Sound Effect), yang membunyikan suara horn yang keras sebagai tanda awal perang dulu. Dalam koreografi ini sebagai awal dimulai waktu berkegiatan di hari hari yang menjemukan menghadapi musim pandemi. Kemudian masuk tarian inti dengan music genre R\&B The King Freestyle Rap Beat Instrumenta INSM Beats. yang disambung dengan Cinematic Action Music Loop (Chase Scene Sound Effect). 
Bagian akhir ada chaos yang didukung oleh sound effect berupa perkusi menutup tarian ini menggunakan musik dari Ambient music instrumental berjudul Solar Granulation Kotak Waktu, ditarikan oleh Ni Made Oliftyansi Santi Dewi mengekspresikan mahasiswi yang berkegiatan di dalam kamar, Paling sering main handphone untuk buat konten Tik Tok, komen atau main game online. Bila bosan lalu buka laptop nonton film di laptop. Durasinya sekitar 7 menit.

Tari Mimpi di atas Impian menggunakan musiktari yang diunduh dari Youtube, yaitu:

Bagian awal hingga tengah diiringi gendhing klenengan Mijil Layu Layu yang merupakan komposisi gendhing klasik yang dipadukan dengan musik ambient yang berjudul Spirit OfThe Earth ciptaan Stive Morgan Lona. Di bagian awal ini ada nuansa tradisional Jawa di era urban yang menjadi simbol dari kerinduan para penari Jawa untuk kembali bisa pentas di musim pandemi.

Bagian akhir menggunakan musik Youtube juga dari Cinematic Movie Trailer Epic Ending Sound Effect, yang menghadirkan suasana chaos. Penari kebingungan mencari upaya alternatif agar bisa tetap menari walau hanya di sosial media.

Peneliti memperhatikan di sosial media yang dominan mengisi Tik Tok, IG Stori dan sejenisnya adalah wanita, bila ada laki laki biasanya ikut kelompok wanita. Setelah observasi dengan wawancara kepada beberapa mahasiswa Tari yang masih kos di Yogyakarta,artinya mahasiswa tidak kembali ke kampung halaman selama Belajar Dari Rumah (BDR). Didominasi mahasiswa wanita, ada beberapa mahasiswa laki laki, malahan sering gabung ke kelompok wanita bila berkegiatan, seperti masak memasak. Pada kenyataannya Prodi Tari memang di dominasi wanita.

Tari ke dua diberi judul Mimpi di Atas Impiandibawakan oleh Tamara Nona Armanda, terinspirasi dari penari yang tidak bisa lagi pentas karena adanya pandemi. Paling tidak seminggu sekali penari bisa pentas untuk acara pariwisata di panggung Prambanan atau pada acara company gathering di Mall atau hotel. Tidak sedikit yang pentas untuk acara pernikahan dan untuk kepentingan Kraton Yogyakarta. Semua kegiatan pentas dibekukan sehingga berimbas pada mahasiswa Tari, biasanya dapat uang pada setiap pentas menjadi tidak ada lagi pemasukan. Kelompok ini yang paling sering melakukan Tik Tok ramai ramai bersama beberapa kawan. Koreografi ke dua juga sekitar 7 menit.

\section{SIMPULAN}

Berkarya tari di musim pandemi memiliki tantangan tersendiri, yaitu memindahkan pergelarannya ke virtual, kelihatannya lebih sederhana tetapi pada kenyataannya tetap melibatkan banyak orang saat persiapan hingga rekaman tari, sehingga biayanya juga cukup banyak dikeluarkan untuk konsumsi dan uang jasa. Apalagi ada pembatasan sosial di kampus, tidak diperbolehkan melibatkan mahasiswa dalamjumlah banyak. Mengatur jadwal latihan dan rekaman diupayakan siang hari di jam kerja, karena kampus ditutup sejak pukul 15.00 hingga esok hari jam kerja pagi jam 08.00.

Belum lagi kesulitan mencari pemusik yang sudah dihubungi lewat telepon, kemudian lupa namanya karena kelamaan jaraknya antara proposal dengan pengumuman diterimanya. Bahkan dianggap tidak jadi ada kegiatan penelitian karena semua dana pemerintah digunakan memerangi pandemi.

Pendekatan intersubyektif yang digunakan dalam menata koreografi Episode Hitam ini memudahkan proses terwujudnya tari. Secara kebetulan masih ada beberapa mahasiswa yang diajak sebagai penariyang tidak pulang kampung selama pandemi. Situasional tersebut membuat perubahan dari semula menata tari duet laki dan perempuan, berubah menjadi dua tarian tunggal dengan penari wanita semua.

Pandemi membuat alternatif ruang pertunjukan baru yaitu virtual melalui media sosial, hal itu menjadi kesempatan belajar mengenali lebih dalam seluk beluk pertunjukan virtual, dan koreografi yang diciptakan ini diunggah di Youtube dan didaftarkan dalam Kekayaan Intelektual di Kemenhumkam Daerah Istimewa Yogyakarta.

\section{DAFTAR RUJUKAN}

Baswedan, Anis. (2020). Peraturan Gubernur Nomor 33 Tahun 2020. tentang pelaksanaan "Pembatasan Sosial Berskala Besar Dalam Penanganan Corona Virus Disease 2019 (COVID-19) di Provinsi Daerah Khusus Ibu Kota Jakarta".

Kompas.com. (15 April 2020). 151040/psbb-jakartamulai-berlaku-ini-yang-boleh-tak-boleh-di-dki. Kompas. Jakarta.

Hadi, Sumandiyo. (2016). Koreografi Bentuk-Teknik-Isi. Cipta Media, Yogyakarta.

Hidajat, Robby. (2005), Wawasan Seni Tari. Pengetahuan Praktis Bagi Guru Seni Tari, Universitas Negeri Malang, Malang.

Martono, Hendro. (2012). Koreografi Lingkungan: Revitalisasi Gaya Pemanggungan dan Penciptaan Seniman Nusantara, Cipta Media, Yogyakarta.

Martono, Hendro. (2012). “Koreografi Lingkungan Memperkaya Metode Penciptaan Tari di Indonesia" dalam Jurnal MUDRA Seni Budaya. Volume 27 no.2 - Juli 2012: 111-118. ISI Denpasar, Denpasar 
Martono, Hendro. (2014). Ruang Berkesenian dan Pertunjukan, Cipta Media, Yogyakarta

Pranita, Ellyvon (15 April 2020) artikel kompas.com "Indonesia Tak Pilih Lockdown untuk Perangi Corona, Begini Kata Ahli”..., Kompas, Jakarta

Smith, Jacqueline. (1976), Dance Composition A Practical Guide For Teachers atau Komposisi Tari Sebuah Petunjuk Praktis Bagi Guru, terjemahan Ben Suharto. IKALASTI YOGYAKARTA (1985), Yogyakarta

Sudewi, N. N., Dana, I. W., \& Cau Arsana, I. N. (2019). Legong Dan Kebyar Strategi Kreatif Penciptaan Tari. Mudra Jurnal Seni Budaya, 34(3), 285-290. https://doi. org/10.31091/mudra.v34i3.784

Sustiawati, Ni Luh. (2011), "Kontribusi Seni Tari Nusantara dalam Membangun Pendidikan Multikultur" dalam Jurnal Mudra Seni Budaya. Volume 26, Nomor 2, Juli 2011: 126-131. ISI Denpasar, Denpasar 